\title{
Finite elements study of the Flexi Post and Flexi Flange post systems in a maxillary central incisor
}

\section{Estudo pelo método dos elementos finitos dos pinos Flexi Post e Flexi Flange em um incisivo central superior}

\author{
Hugo Roberto Lewgoy* \\ Michel Nicolau Youssef** \\ Maurício Rufaiel Matson*** \\ Jorge Antônio Javier Saldivar Bocangel* \\ Camillo Anauate Netto**** \\ Ricardo Amore ${ }^{* * * * *}$
}

\begin{abstract}
The use of post and core systems has become an excellent alternative for restoring endodontically treated teeth. The aim of this study was to evaluate the von Mises, maximal compressive and tensile stresses distribution using the Finite Element Method (FEM) on human teeth restored with different post and core systems. The analysis was made on endodontically treated maxillary central incisors. The post systems used in this investigation were the stainless steel or titanium Flexi Post/Flexi Flange. Composite resin was used as core material and resin cement was the cement material of choice to seat a full porcelain crown. The bi-dimensional mathematical model was created from pictures taken from an intact human maxillary central incisor and prefabricated posts. This image was transferred to a personal computer in the MSC/Nastran 4.5 software. A static and linear analysis treatment was performed when a $45^{\circ}$ load of $100 \mathrm{~N}$ was applied on the lingual surface of the tooth. Based on the results obtained, it can be concluded that the post design and its material can alter the stress pattern distribution.

DESCRIPTORS: Finite element analysis; Post and core technique; Dental pins.
\end{abstract}

\begin{abstract}
RESUMO: A utilização de pinos intra-radiculares tem se mostrado uma excelente alternativa para dentes endodonticamente tratados. Este trabalho teve como objetivo avaliar, utilizando o Método dos Elementos Finitos (MEF), como pinos intra-radiculares pré-fabricados metálicos podem alterar o padrão das tensões geradas de von Mises e de máxima tração e compressão na raiz dental. A comparação foi realizada entre os pinos pré-fabricados Flexi Post/Flexi Flange de aço inoxidável e titânio com preenchimento coronário em resina composta. Os pinos intra-radiculares foram fixados com um cimento resinoso e recobertos por uma coroa total cerâmica. A partir de fotografias da peça anatômica e dos pinos estudados, foram criados modelos matemáticos bidimensionais no programa MSC/Nastran 4.5 e, após aplicação de uma força de $100 \mathrm{~N}$ a 45 graus na superfície palatina dos modelos, foi avaliada a distribuição das tensões geradas. Com base nos resultados obtidos, pode-se concluir que os pinos intra-radiculares alteram o padrão das tensões geradas dependendo do desenho do pino intra-radicular e do tipo de material constituinte.
\end{abstract}

DESCRITORES: Análise de elemento finito; Técnica para retentor intra-radicular; Pinos dentários.

\section{INTRODUCTION}

The reconstruction of endodontically treated teeth with great loss of tooth structure using post and core systems is a routine in Restorative Dentistry. The stress distribution during masticatory function in an endodontically treated tooth restored with post and core can cause root fracture, especially in anterior teeth undergoing tangential forces. The prefabricated posts available in the marketplace can be categorized as active and passive. Among the active posts there are some with an anti-stress device. This characteristic may allow this system to be classified as partially active or active-passive, according to its manufacturers.

Developments in the research area allowed the appearance of a method that provides sufficient and accurate information concerning the state of stress on the tooth structure. The Finite Element

\footnotetext{
*Doctorate Students; **Full Professor - Discipline of Restorative Dentistry, School of Dentistry, University of São Paulo.

***Professor, Chairman, Discipline of Restorative Dentistry, School of Dentistry, Ibirapuera University.

****Adjunct Professor, Discipline of Restorative Dentistry, School of Dentistry, University of Mogi das Cruzes.

*****Doctorate Student, Discipline of Restorative Dentistry, School of Dentistry, State University of São Paulo.
} 
Lewgoy HR, Youssef MN, Matson MR, Bocangel JAJS, Anauate Netto C, Amore R. Finite elements study of the Flexi Post and Flexi Flange post systems in a maxillary central incisor. Pesqui Odontol Bras 2003;17(2):132-6.

Method (FEM) has been widely used in engineering, and in the last two decades has proved to be extremely effective in dentistry as well. In a simple manner, Matson ${ }^{9}$ (1996) describes the finite element analysis as being a numerical model of structure analysis and continuous elements. The structure to be analyzed is divided in small points (called elements) interconnected at a finite number of points (called nodal points). In the biomedical field, the FEM is an important method since it can avoid the necessity of traditional specimens; and by using a mathematical model it eliminates the need of a large number of teeth. Arola et al. ${ }^{1}$ (2001) stated that the FEM is fundamental in the studies that investigate stresses generated in restored teeth. The stress distribution in the cervical, middle and apical areas of the root is extremely important, therefore it is important that the shape and type of the material be less traumatic to the dental root during masticatory function.

\section{PROPOSITION}

The purpose of this work was to analyze the stress distribution in a central incisor restored with the prefabricated posts Flexi Post or Flexi Flange (EDS-Essential Dental Systems, South Hackensack, NJ, USA) by the Finite Element Method.

\section{MATERIAL AND METHOD}

To create the mathematical model for the present study, an anatomic model of a maxilla containing anterior teeth with enamel, dentin, pulp chamber, periodontal ligament, cortical bone and trabecular bone delimitations was used. This anatomic model was photographed with the aid of a stereoscopic magnifying glass and the image was stored in a computer. This image was printed and its structures contours were delimitated. The figure thus obtained was digitalized in a SummaSketch III table (Summagraphics Corporation, New York, NY, USA). In order to create a digitalized model, a Finite Element Method program, MSC/Nastran 4.5 for Windows (The MacNealSchwendler Corporation, Savannah, GA, USA), was used. The program developed elements automatically, determining all the structures in a two-dimensional form. The posts were selected according to the anatomy of the incisors photographed, and inserted into the preexisting sound tooth as described before. Composite resin was used as core material and resin cement was the ce- ment material of choice to seat a full porcelain crown. All properties of the materials used were described before in the literature (Bocangel ${ }^{2}, 1999$; Matson $^{10}$, 2000). A perpendicular load was applied to the lingual surface, 45 degrees with the long axis of the tooth with a load of $100 \mathrm{~N}$ in order to analyze the stress generated by the prefabricated post.

\section{RESULTS AND DISCUSSION}

When an intra-radicular post is used, the system of choice should generate the least amount of tension, which will affect the longevity of the restoration. The prefabricated posts Flexi Post and Flexi Flange (EDS Inc.) were compared because they represent an alternative choice for the custom metallic post. In the model in which the prefabricated stainless steel Flexi Post was simulated, an interesting von Mises stress distribution was observed. At the support structure area, the stress was distributed evenly, without large concentrations in specific areas. The radicular area that attracted more attention was the middle third because that is where the split-shank post generates more stress, approximately 96.29 MPa. The split-shank design has the purpose of dissipating the stress produced when the post is being inserted in the root canal. This opening helps the post to deflect and not transmit stress to the dental root in an aggressive way. On the other hand, the stainless steel post has a high elasticity modulus, and the coronal stress is concentrated to a high level before it dissipates to the supporting structures that present a uniform distribution pattern, although in high magnitude. The stresses exerted by a stainless steel Flexi Post can be observed in Figure 1.

The maximum compressive load stress concentration was observed at the buccal cortical bone, and the tensile stress concentration was located at the palatal cortical bone. The palatal area of the post caused a compressive load stress of approximately $28.9 \mathrm{MPa}$, and the buccal area had a high-tensile stress concentration at the junction between the rigid part and the split of approximately $39.3 \mathrm{MPa}$. The stress distribution occurs while rotating the post towards the palatal side. When torsional forces are applied the leg of the post compresses on itself, resulting in tensile stress. The central part of the post has two legs, and when force is applied this opening closes and stress is created. If, after this force, the post overreacts in order to keep it open, it will generate sec- 
Lewgoy HR, Youssef MN, Matson MR, Bocangel JAJS, Anauate Netto C, Amore R. Finite elements study of the Flexi Post and Flexi Flange post systems in a maxillary central incisor. Pesqui Odontol Bras 2003;17(2):132-6.

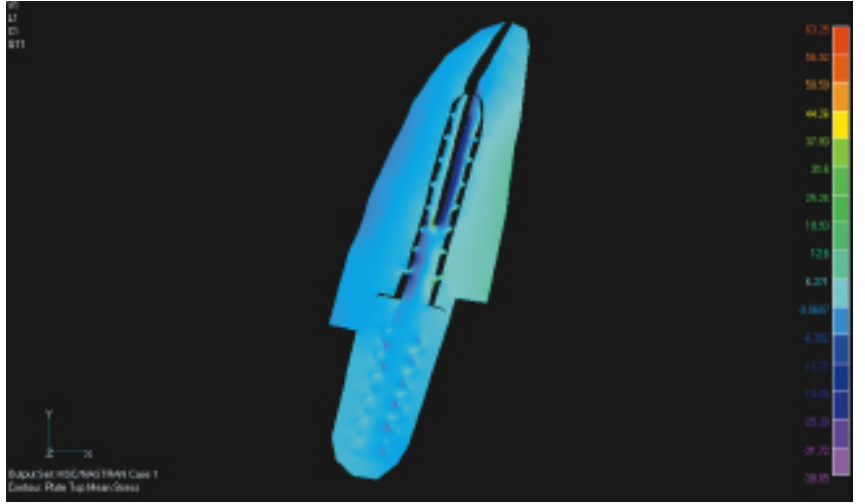

FIGURE 1 - Maximum tensile and compressive load stresses for the stainless steel Flexi Post.

ondary stresses on the tooth structure. Something that is important in the stainless steel Flexi Post system is the high magnitude of stresses found. A significant difference of stress distribution is noticed when the post material is replaced by titanium. A high concentration of von Mises stresses on the post near the split, and a low stress concentration on the tooth and surrounding structures were observed. Beside the post, von Mises stress showed a maximum of $25 \mathrm{MPa}$ for the tooth and surrounding structures. This value is relatively low if compared with that of the stainless steel post, in which the stresses can be $35 \mathrm{MPa}$. Despite the absence of high stress concentration on the tooth structure, a point of interest is the stress accumulation at the junction between the split and the rigid part of the post. The palatine side near the middle third of the root can present stresses at 63.2 $\mathrm{MPa}$, evidencing the stress concentration on the post. The stresses on the intra-radicular titanium Flexi Post can be observed in Figure 2.

Regarding the tensile and compressive stresses, the same pattern for both post systems was described but with different numbers. The tensile stress went up to $12.6 \mathrm{MPa}$, while the compressive stress was $12.7 \mathrm{MPa}$. Comparing these values to those reported in other studies a decrease in the tensile stress of approximately 102\% in compression and $311 \%$ in tensile stress could be verified. The stainless steel Flexi Post system presented higher numbers than the titanium Flexi Post system. This can be explained by the fact that the elasticity modulus of stainless steel is higher than that of titanium, resulting in significantly higher numbers. The rigidity of the material is related to the magnitude of the stresses produced. The stress

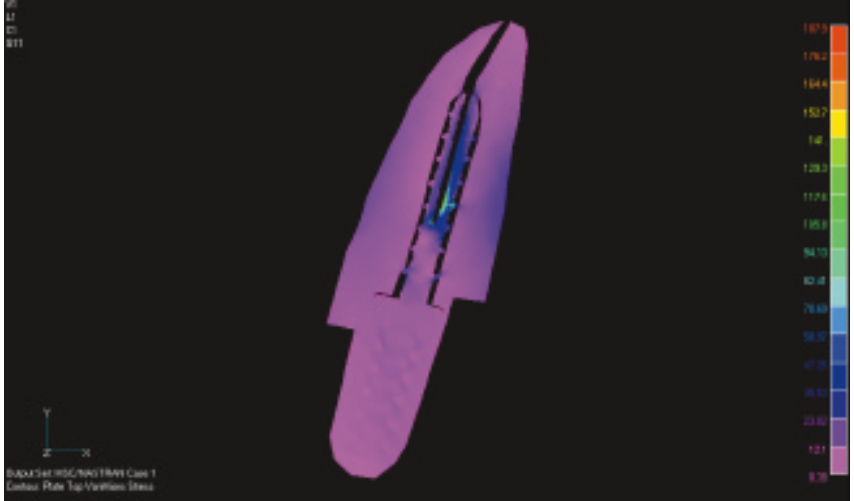

FIGURE 2 - von Mises stresses on the titanium Flexi Post.

distribution at the flange area is approximately 17.9 $\mathrm{MPa}$ for the stainless steel Flexi Flange post system. The same post system decreases this stress magnitude when there is no flange. The stainless steel Flexi Flange post system presents a von Mises stress concentration about 14\% lower than that of the stainless steel Flexi Post. This fact can be observed in the upper third of the stainless steel Flexi Flange post, where stresses reach approximately $26.7 \mathrm{MPa}$. This number is 34\% lower than that of the stainless steel Flexi Post, which reached $35.9 \mathrm{MPa}$. The flange acts as a stop, reducing the accumulation of stress on the post, maintaining the same value on the surrounding structures and reducing the stress on the dentin. It should be emphasized that the flange's function is to stabilize the post and distribute the stress to a lower intensity in the cervical radicular area. This statement is in accordance with the findings of the present study. Stress caused by the stainless steel Flexi Flange post can be observed in Figure 3.

When comparing the different Flexi Flange's materials, it could be noticed that the maximum tensile and compressive stresses were higher in the stainless steel system than in the titanium system. This difference is very clear, since the stainless steel elasticity modulus is higher than that of titanium. Regarding the stresses close to the split, an increase of stress of approximately $101 \%$ for the stainless steel can be observed. This value demonstrates how much a material can interfere with the stress generation since both posts systems have the same design. Despite this stress concentration, a significant decrease of stress on the supporting structure was observed: $39.4 \mathrm{MPa}$ at the split-shank and 22.8 MPa at the buccal and lin- 
Lewgoy HR, Youssef MN, Matson MR, Bocangel JAJS, Anauate Netto C, Amore R. Finite elements study of the Flexi Post and Flexi Flange post systems in a maxillary central incisor. Pesqui Odontol Bras 2003;17(2):132-6.

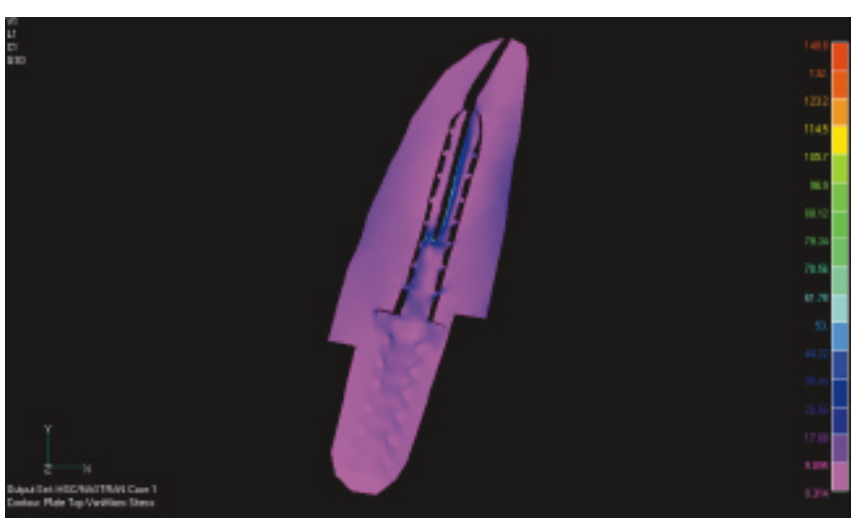

FIGURE 3 - von Mises stresses on the stainless steel Flexi Flange post.

gual cortical bone. The stresses generated on the titanium Flexi Flange post are demonstrated in Figure 4.

According to Trabert et al. ${ }^{13}$ (1978); Spangler ${ }^{12}$, (1980); Reinhardt et al. ${ }^{11}$, (1983); and Holmes et $a l^{8}$, (1996), the apical root region is an area of extreme attention and care. At the apical part of the post there was a homogeneous stress concentration with accumulation points, albeit with a high magnitude of stress in relation to the sound dental structure. The reason for this fact is probably the split-shank of the Flexi Post/Flexi Flange post systems. Another reason could be the round end of the retainers that preserves the apical third of the dental structure. As regards the maximum tensile and compressive stresses, the stress pattern created was similar to that of the stainless steel Flexi Flange post system, but with stress distribution at a lower magnitude. One important characteristic of the stainless steel Flexi Flange post system is the compression stress distribution. The dental structure is more capable of resisting compressive forces than tensile forces. The periodontal ligament acts as a stress absorber, dissipating uniformly and homogeneously the stresses generated on the dental and surrounding structures. The tensile stresses accumulate in a lower magnitude in the palatine side of the radicular dentin and cortical bone, due to the buccal-apical movement that the tooth structure tends to perform. This stress distribution pattern could be related to the presence of the flanges on the posts, since the only difference between these posts is the presence of this stop ring that lies on the radicular cervical dentin. This statement is in accordance with the studies done by Cohen et al. ${ }^{4,5,6}$ (1994; 1997; and 2000)

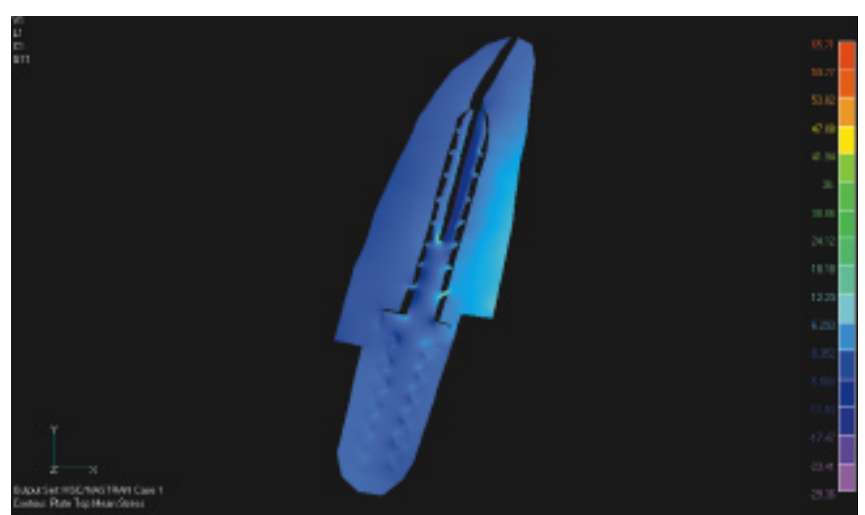

FIGURE 4 - Maximum tensile and compression stresses on the titanium Flexi Flange post.

and Deutsch et al. ${ }^{7}$ (1997). The stresses generated are approximately between $-5.5 \mathrm{MPa}$ and 18.1 $\mathrm{MPa}$. This means that the compression stresses vary from a maximum of $5.5 \mathrm{MPa}$ up to a tensile maximum of $18.1 \mathrm{MPa}$. For titanium, these values can vary but are maintained in a small range, which makes the stress distribution safer. The stainless steel post distributions occur in a larger range with differences of $-2.4 \mathrm{MPa}$ and $57.4 \mathrm{MPa}$ approximately. Cailleteau et al. ${ }^{3}$ (1992) suggests to reject the idea that an intra-radicular post can distribute the stresses generated during mastication or reinforce the remaining dental structure due to a stress distribution pattern caused by a rigid coronal portion. The insertion of an intra-radicular post results in a coronal structure more rigid and alters the modulus of elasticity of the tooth, changing its position more apically when compared to a sound tooth. In this situation the apical part of the root without the post is under more stress. This statement can be eased depending on the post system used.

Besides the findings of this investigation it is important to mention that other factors that have not been addressed here are also very important such as post retention and masticatory load dynamics. The FEM picture demonstrated a static situation at the moment of load application and not an actual clinical scenario. It is therefore recommended that further investigation be carried out in order to confirm the findings of the present study.

\section{CONCLUSIONS}

1. The teeth restored with stainless steel or titanium Flexi Post and stainless steel or titanium Flexi Flange had a homogeneous stress distri- 
Lewgoy HR, Youssef MN, Matson MR, Bocangel JAJS, Anauate Netto C, Amore R. Finite elements study of the Flexi Post and Flexi Flange post systems in a maxillary central incisor. Pesqui Odontol Bras 2003;17(2):132-6.

bution, but with pronounced magnitude when compared to that of the dental structure. The stainless steel Flexi Post and Flexi Flange post systems had a higher stress distribution than did the titanium posts.

2. The stainless steel and titanium Flexi Flange posts distribute the stress more homogeneously and with a lower magnitude in compar- ison to the stainless steel and titanium Flexi Post. The flange could be the only cause for this difference.

3. In general, the maximum compression stress is concentrated at the buccal side and the tensile stresses are concentrated at the lingual side when a 45 degree load is applied on a central incisor.

\section{REFERENCES}

1. Arola D, Galles LA, Sarubin MF. A comparison of the mechanical behavior of posterior teeth with amalgam and composite MOD restorations. J Dent Res 2001;29:63-73.

2. Bocangel JAJS. Estudo das tensões geradas em dentes integros e com tratamento endodôntico, restaurados com retentores intra-radiculares de diferentes materiais e coroa total em porcelana [Dissertação de Mestrado]. São Paulo: Faculdade de Odontologia da USP; 1999.

3. Cailleteau JG, Rieger MR, Akin JE. A comparison of intracanal stresses in a post-restored tooth utilizing the finite element method. J Endod 1992;18:540-4.

4. Cohen BI, Condos S, Deutsch AS, Musikant BL. Fracture strength of three different core materials in combination with three different endodontic posts. Int $\mathrm{J}$ Prosthodont 1994;7:178-82.

5. Cohen BI, Pagnillo MK, Newman I, Musikant BL, Deutsch AS. Cyclic fatigue testing of five endodontic post designs supported by four core materials. $J$ Prosthet Dent 1997;78:458-64.

6. Cohen BI. Pagnillo MK, Newman I, Musikant BL, Deutsch AS. Pilot study of the cyclic fatigue characteristics of five endodontic posts with four core materials. J Oral Rehabil 2000;27:83-92.
7. Deutsch AS, Musikant BL, Cohen BI. Rational predictable posthole preparation. Compend Contin Educ Dent 1997; 18:626-34.

8. Holmes DC, Diaz-Arnold AM, Leary JM. Influence of post dimension on stress distribution in dentin. J Prosthet Dent 1996;75:140-7.

9. Matson MR. Estudo das tensões de von Mises em dentes integros e dentes que receberam facetas laminadas de porcelana [Dissertação de Mestrado]. São Paulo: Faculdade de Odontologia da USP; 1996.

10. Matson MR. Estudo das tensões geradas em dentes pré-molares superiores integros e com restauração em resina composta na região cervical vestibular [Tese de Doutorado]. São Paulo: Faculdade de Odontologia da USP; 2000.

11. Reinhardt RA, Krejci RF, Pao YC, Srannard JG. Dentine stresses in post-reconstructed teeth with diminishing bone support. J Dent Res 1983;62:1002-8.

12. Spangler CC. Post and cores: some new ideas. Dent Surv 1980; 56:33-5.

13. Trabert KC, Caputo AA, Abou-Rass M. Tooth fracture: a comparison of endodontic and restorative treatments. J Endod 1978;4:341-5.

Recebido para publicação em 04/02/02

Enviado para reformulação em 11/08/02

Aceito para publicação em 14/04/03 